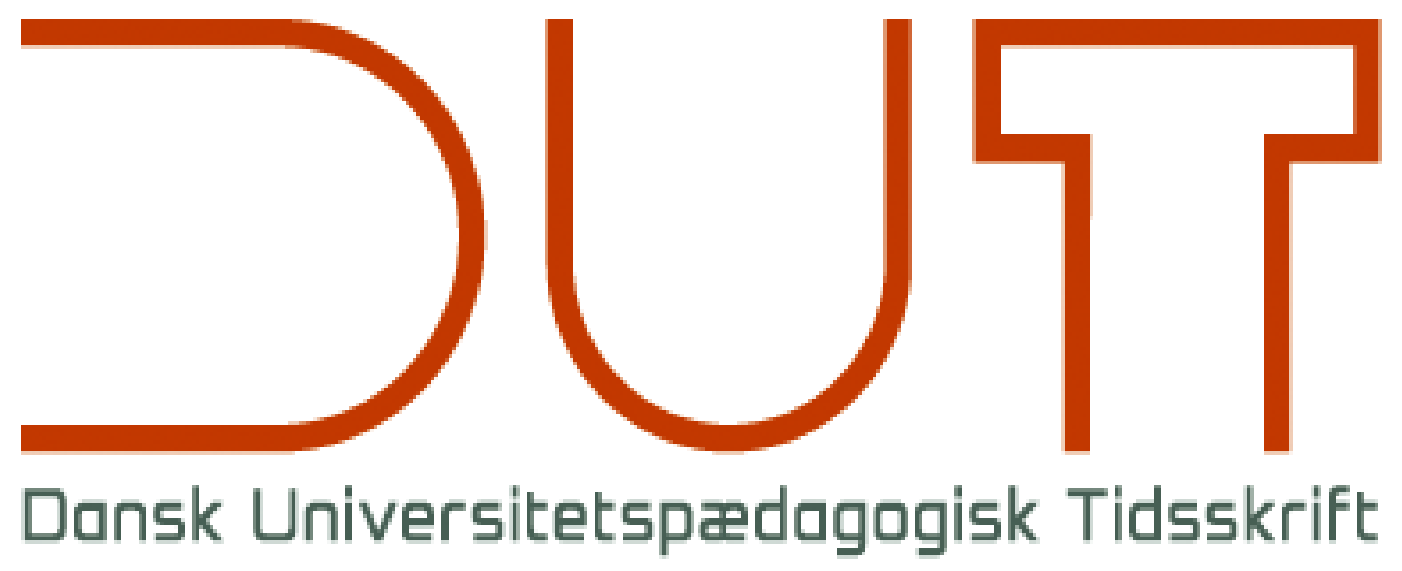

Tema

Ledelse, udvikling og overlevelse på universitetet

Årgang 12 nr. 22 / 2017

Titel

Når der eksamineres mundtligt - eksaminators rolle og indhentning af bedømmelsesgrundlag i sundhedsuddannelser

Forfatter

Sidetal

Thomas Würtz Jensen, Winnie Westergaard Høgsaa og Carsten Nielsen

$75-87$

Udgivet af

Dansk Universitetspædagogisk Netværk, DUN

URL

> http://dun-net.dk/

Betingelser for brug af denne artikel

Denne artikel er omfattet af ophavsretsloven, og der må citeres fra den. Følgende betingelser skal dog være opfyldt:

- Citatet skal være i overensstemmelse med "god skik“

- Der må kun citeres „i det omfang, som betinges af formålet“

- Ophavsmanden til teksten skal krediteres, og kilden skal angives ift. ovenstående bibliografiske oplysninger. 


\title{
Når der eksamineres mundtligt - eksaminators rolle og indhentning af bedømmelsesgrundlag i sundhedsuddannelser
}

\author{
Thomas Würtz Jensen, lektor, PT, MIL, VIA University College \\ Winnie Westergaard Høgsaa, lektor, cand.cur., VIA University College \\ Carsten Nielsen, lektor, cand.pæd., VIA University College
}

\section{Reviewet artikel}

Litteraturreview viser, at mundtlig eksamination kun i begrænset omfang er videnskabeligt undersøgt. Studiet har fokus på eksaminatorrollen og opgaven med at indhente bedømmelsesgrundlag ved bacheloreksamen.

Der er anvendt kvalitative metoder med observation og lydoptagelse af mundtlige eksaminationer og efterfolgende individuelle semistrukturerede interviews med eksaminanden og eksaminator. 12 eksaminationer indgik i studiet. Der blev analyseret på baggrund af analysekategorier genereret gennem litteraturreview og fokusgruppeinterviews med eksaminatorer. Studiet viser, at det er en kompleks og udfordrende opgave at varetage eksaminatorrollen med udgangspunkt i en større skriftlig projektopgave. Der skal foretages komplicerede valg, når eksaminationstiden skal bruges optimalt til at skaffe et relevant bedømmelsesgrundlag. Der er spændingsfelter, som eksaminator skal navigere i. Det kan konstateres, at eksaminatorerne navigerer i disse spændingsfelter på forskellig vis. Noget af forskellen kan forklares med, at eksaminationerne er tilpasset konkrete eksaminander og tager udgangspunkt i specifikke skriftlige projekter. Det er kendetegnende, at eksaminatorerne ikke tillægger deres forforståelse af eksaminanden stor betydning.

\section{Baggrund}

Afsluttende bachelor- og kandidateksaminationer har afgørende betydning for eksaminanden og er en betroet samfundsmæssig opgave, hvorfor det er vigtigt, at den bliver gennemført på en professionel måde.

Et gennemført litteraturreview med systematisk søgning i databaserne ERIC, PROQUIST og Cinahl afdækker, at mundtlig eksamination på baggrund af større skriftlige projekter kun i meget begrænset omfang har været underkastet forskningsmæssig interesse.

Der findes en del nordisk litteratur, hvor man som eksaminator kan hente råd om eksamination og eksaminatorrollen (Agersnap, 2004; Hedelund \& Stray Jørgensen, 
2004; Hørdam, Hundborg, \& Christiansen, 2011; Leth Andersen \& Tofteskov, 2008; Kristensen, 2014), men der er ingen deskriptiv forskningsmæssig afdækning af området som afsæt for disse råd.

Artiklen vil give svar på nedstående forskningsspørgsmål:

Hvordan varetages eksaminatorrollen ved mundtlige eksaminationer på baggrund af en skriftlig projektopgave, og hvad har betydning for indhentning af bedømmelsesgrundlaget?

\section{Metode}

Undersøgelsen tager udgangspunkt i den afsluttende individuelle mundtlige bacheloreksamination på baggrund af et skriftligt gruppeprojekt. Eksaminationerne er afviklet ved sundhedsfaglige bacheloruddannelser i fysioterapi, ergoterapi og sygepleje ved et dansk University College.

\section{Design}

Undersøgelsen er gennemført som et kvalitativt eksplorativt empirisk studie med inspiration fra etnografisk metode (Borgnakke, 2013).

Sideløbende med litteraturreview rettet mod eksisterende viden på området er der, som forberedelse til hovedprojektet, gennemført tre fokusgruppeinterviews (Krueger, 2015) med erfarne eksaminatorer fra de tre professionsfaglige sundhedsuddannelser om eksaminatorrollen. Interviews sammenholdt med fund fra litteraturgennemgangen dannede baggrund for konstruktion af observations- og interviewguides samt analysestrategi, som blev pilottestet på fem mundtlige bacheloreksaminationer. På baggrund af pilotprojektet blev designet forfinet til brug i hovedprojektet.

\section{Deltagere og rammer for dataindsamling}

I hovedprojektet indgik 12 mundtlige eksaminationer, heraf tre i ergoterapeutuddannelsen, tre i fysioterapeutuddannelsen og seks i sygeplejerskeuddannelsen. Det var vores vurdering, at 12 eksaminationer kunne give et nuanceret billede af afviklingen.

Udvælgelse af deltagere skete efter skriftlig henvendelse til erfarne eksaminatorer på de tre uddannelser. Eksaminanderne og censorerne blev efterfølgende spurgt, om de ville deltage, og alle indvilligede. Vi har ikke indsigt $\mathrm{i}$, hvad der fik eksaminatorer til at tilbyde eller fravælge deres deltagelse.

\section{Dataindsamling}

I projektet er der anvendt datatriangulering (Elo \& Kyngäs, 2008; Polit \& Beck, 2012) med anvendelse af lydoptagelse af eksaminationerne, observationsstudier med feltnoter (Borgnakke, 2013) og efterfølgende interviews med såvel eksaminatorerne som eksaminanderne (Kvale \& Brinkmann, 2015). 
Observation med tilhørende feltnoter samt lydoptagelse af eksaminationerne blev anvendt for at generere data om eksaminationsafviklingen og til målretning af de efterfølgende interviews.

Semistrukturerede interviews med eksaminatorer blev anvendt for at få indsigt i eksaminators vurderinger og begrundelser knyttet til eksaminationsforberedelsen og afviklingen af selve eksaminationen.

Semistrukturerede interviews med eksaminanderne blev anvendt for at få indsigt i, hvordan de oplevede deres mulighed for at vise deres faglige niveau under eksaminationen.

Interviews blev gennemført af observatøren ud fra en semistruktureret interviewguide, som gav plads til at inddrage observationer fra den mundtlige eksamination. Interviewene havde en varighed på ca. en halv time.

\section{Etik}

Uddannelses- og Forskningsministeriet gav tilladelse til at observere og foretage lydoptagelse af de mundtlige eksaminationer. Lederne af de tre uddannelser gav tilladelse til at gennemføre undersøgelsen. Eksaminatorer, studerende og censorer gav skriftligt tilsagn om deltagelse.

\section{Analysemetode}

Der er anvendt en deduktiv indholdsanalyse af det samlede datamateriale med udgangspunkt i udledte analysekategorier genereret gennem litteraturstudier, fokusgruppeinterviews og pilotstudie, som indfanger centrale kategorier i forhold til mundtlig eksamination (Elo \& Kyngäs, 2008). De overordnede analysekategorier til kodning var: forberedelse, forforståelse, styring, spørgsmålstyper og stemning. I kodning af data har der kontinuerligt været en proces med sikring af korrespondance mellem kodningen af datamaterialet og kategorierne (Polit \& Beck, 2004). Validering af kodningerne er understøttet gennem uafhængig kodning fra de tre forskere. De udviklede kategorier er anvendt som redskaber i den analytiske proces og kan ikke anskues som uafhængige kategorier, hvilket fx kan ses, ved at samme data er kodet i forhold til flere forskellige kategorier.

De forskellige datatyper knyttet til det enkelte eksaminationsforløb er analyseret hver for sig, og efterfølgende er der foretaget en tværgående analyse. Datatrianguleringen har givet mulighed for at belyse aspekter i eksaminationerne ud fra forskellige datakilder og ud fra såvel en eksaminand- som en eksaminatorvinkel. Afsluttende blev der foretaget en tværgående analyse af de 12 eksamensforløb.

Interviews og lydoptagelser blev gennemlyttet, og centrale passager blev transskriberet i Microsoft OneNote, hvor lydbilledet bevares, så det kan aktiveres ved at klikke på tekstdele. 
Der er anvendt forskertriangulering i kodning og analysen af de forskellige datatyper, hvor hver deltager indledningsvis kodede data, og efterfølgende blev der opnået enighed om kodningerne gennem diskussion og konsultation af data.

\section{Resultater}

Resultatet af analysen har form at en beskrivende opsummering af de genererede fund i forhold til de overordnede analysekategorier: forberedelse, forforståelse, styring, spørgsmålstyper og stemning.

\section{Forberedelse}

De fleste eksaminatorer nævner, at de på et eller andet niveau bruger prøvekriterierne i deres forberedelse, men de faglige og metodiske tematikker udledt af læsningen af bachelorprojektet synes at være det centrale i deres forberedelse. Det er typisk uklarheder og svagheder i argumentationen i opgaven, der giver anledning til identifikation af tematikkerne. De fleste eksaminatorer har udarbejdet eksamensspørgsmål til de udvalgte tematikker, men enkelte har alene overordnede tematikker til styring af eksaminationen.

\section{Forforståelse}

Eksaminatorernes relation og kendskab til eksaminanden fra den forudgående vejledningsproces er ikke et forhold, eksaminatorerne tillægger en særlig betydning. De mener, at deres forforståelse af eksaminanden især er opbygget gennem deres læsning af projekterne. Læsningen danner ifølge eksaminatorerne udgangspunkt for deres udvælgelse og prioritering af tematikker samt for sværhedsgraden af spørgsmål. Der er dog eksempler på, at samspillet i vejledningsforløbet har påvirket forforståelsen. En eksaminator havde oplevet eksaminanden som dygtig under vejledningsprocessen og udtaler: "Jeg havde rigtig meget lyst til at tale den her studerende så højt op som muligt". En anden havde omvendt svage forventninger med udgangspunkt i vejledningsforløbet, men måtte justere eksaminationen, da eksaminanden svarede 'rigtigt godt for sig.

Eksaminanderne kommer spontant ind på betydningen af deres relation til eksaminator under vejledningsprocessen. De fleste eksaminander har oplevet en god proces og opbygget en tryghed ved eksaminator, som de oplever bliver bekræftet under eksaminationen. Eksaminander, der har oplevet vejledningsforløbet som problematisk, oplever at dette forsætter inde i eksamenslokalet: "Jeg synes ikke, at vi har mødt hinanden på noget tidspunkt. Der er noget i vores kemi. Vi tøede lidt op i vores møde undervejs, men det blev hele tiden et meget anspændt forhold". De mere problematiske relationer kan iagttages under eksaminationsforløbet i form af eksempelvis meget lidt øjenkontakt, manglende anerkendende gestik, en konfronterende spørgeteknik eller ved problemer med at forstå spørgsmål. 


\section{Styring}

Eksaminatorerne tager som beskrevet primært udgangspunkt i tematikker udledt af deres læsning af bachelorprojektet og i mindre grad i kriterierne. Selv om professionsfaglige og metodiske aspekter synes ligestillet i kriterier og mål, er der flere eksaminatorer, der finder, at metode er det centrale i eksaminationen: "Metoden fylder jo også meget i denne her eksamen, ikk?".

Udgangspunkt i tematiseringer kan give bredde i eksaminationen, men der er eksempler på, at eksaminationer forbliver i afgrænsede tematikker: "Jeg bliver i et område, hvor den studerende ikke svarer sufficient, til det er afdækket, eller den studerende har erkendt, at afdækningen i opgaven ikke er fyldestgørende eller korrekt". Eksaminander oplever, at de ved sådanne eksaminationer ikke får mulighed for at demonstrere bredden i deres viden. "Hun kunne have gjort et arbejde for at komme mere rundt, så hun havde haft et bedre grundlag for at bedømme mig". "Tænkte nogen gange undervejs. Har jeg ikk'vist, at jeg ikke kan det". Omvendt kan en eksamination sprede sig over mange temaer, hvilket som tendens gør, at eksaminationen bliver relativt overfladisk. En eksaminator siger: "Hvis de ikke kan svare, går jeg videre med noget andet".

Eksaminationernes forløb og indhold styres overvejende af eksaminator. Det eneste tidspunkt, hvor eksaminanderne har styringen, er i forbindelse med det indledende oplæg på fem-10 minutter. Typisk følger eksaminator op med et enkelt eller måske to afgrænsede spørgsmål og går herefter videre ud fra de tematikker, denne forud har forberedt. Flere eksaminander har en oplevelse af, at oplægget ikke fik nogen betydning: "Jeg synes ikke, at (navn udeladt) evnede at folge op på mit oplæg. Der kom nogle spørgsmål, som jeg slet ikke havde forventet".

Flere eksaminander har en forståelse af, at selvstændig styring vurderes positivt, og de mener, at eksaminator forud for eksaminationen har opmuntret dem til at tage styringen: "Jeg synes ikke, det blev imødekommet. Jeg fik ikke mulighed for at udfolde det, jeg havde forberedt. Jeg synes ikke, jeg fik mulighed, og jeg blev afbrudt". Underviserne er generelt meget hurtige til at stille et nyt spørgsmål, når eksaminander har afsluttet besvarelsen af det foregående. Der er en eksaminator, som direkte har meddelt eksaminanderne forud for eksaminationen, at de ikke skal forsøge at styre.

De fleste eksaminatorer og censorer synes at have en konsensus om, at censor holder lav profil: "Det betyder noget, at der er et godt flow i eksaminationen, så censor skal helst ikke bryde ind". I to eksaminationer var censor meget aktiv og her udtaler eksaminatorerne, at de foretrækker aktive censorer. Eksaminanderne synes at acceptere censorrollen, uanset hvordan den tager sig ud. 


\section{Spørgsmålstyper}

Næsten alle spørgsmål lægger op til, at eksaminanden kan svare med belæg i fagets teorier og metoder, som de studerende selv kan vælge. I enkelte tilfælde spørges der til specifikke teorier og metoder.

Langt de fleste spørgsmål er forståelige for eksaminanden. Der er dog også eksempler, hvor eksaminanderne ikke forstår intentionen: "(navn udeladt) stillede meget åbne spørgsmål, men på en måde, hvor jeg ikke altid kunne fange, hvor (navn udeladt) ville hen", "(navn udeladt) stillede meget komplicerede spørgsmål og brugte begreber og ord, som jeg ikke havde hørt før, og som ikke indgär i nogen af de pensumbøger, vi bruger". I en del tilfælde tager eksaminanden selv initiativ til at få afklaret forståelsen af spørgsmålet og i andre tilfælde omformulerer eksaminator på eget initiativ spørgsmålene.

\section{Stemning}

Eksaminatorerne ønsker at skabe en stemning under eksaminationen, der kan fremme eksaminandernes præstation, og de fleste eksaminander finder, at det lykkes. Eksaminatorerne bruger et åbent kropssprog, søger øjenkontakt og anvender en anerkendende verbal og nonverbal tilgang under eksaminationerne ved at nikke og smile. Mange eksaminander giver udtryk for, at det er vigtigt at kunne 'læse eksaminator'. Eksaminanderne reagerer stærkt på, hvad de oplever som et lukket kropssprog og manglende anerkendende gestik: "Jeg var meget overrasket over, at jeg ikke blev mødt med et smil, da jeg skulle ind. Overrasket over det nonverbale og at (navn udeladt) slet ikke smilede. Der var en stivhed og et lidt koldt udtryk". "Når man kan mærke, at der ikke er imødekommenhed, så bliver jeg usikker og begynder at famle. Det har en kæmpe betydning for mig".

Hvis eksaminator anvender mange konfronterende spørgsmål, og disse hovedsageligt tager afsæt i svage steder i projektopgaven, kan det give anledning til usikkerhed og frustration hos eksaminanden: "Det gik helt forfærdeligt. Jeg mener helt klart, at jeg kan mere end den karakter, der kom til udtryk. Jeg havde meget den der følelse af hele tiden at kæmpe for at følge med og ikke have overskud og overblik".

Der er eksaminationer, hvor eksaminatorerne forekommer neutrale i både den nonverbale og verbale kommunikation, men hvor eksaminanderne alligevel beskriver dem som anerkendende og behagelige at være til eksamen hos.

Censorerne har generelt set ikke den store betydning for eksaminandernes oplevelse af stemningen, uanset om de har en tilbagetrukket eller aktiv rolle. Eksaminator er den centrale figur: "Jeg var mest irriteret på eksaminator. Jeg har sådan et billede, ja, man har en censor som skal være kritisk og bore ned. Jeg har et billede af, at man har en eksaminator, som også skal hjælpe én lidt". 


\section{Resultatdiskussion}

Der er et stort ansvar forbundet med eksaminationen, da der er meget på spil for eksaminanden. Eksaminationen skal sikre et fyldestgørende bedømmelsesgrundlag herunder '... dokumentere, i hvilken grad den studerende opfylder de faglige mål, der er fastsat for uddannelsen og dens elementer ((Undervisningsministeriet, 2014) §2). Diskussionen af eksaminationerne vil gå på tværs af analysekategorierne.

\section{Hvem styrer eksaminationen?}

Kilderne inden for mundtlig eksamination slår fast, at det er eksaminators ansvar at sikre, at der ved eksaminationen skaffes et relevant bedømmelsesgrundlag, men at eksaminanden kan få en vis rolle i styringen (Hørdam, Hundborg \& Christiansen, 2001; Fibiger \& Søgaard, 2009; Laugesen Kristensen, 1999; Hedelund \& Stray Jørgensen, 2004; Kristensen 2014). Enkelte kilder anbefaler, at eksaminator kun skal skride ind og tage styringen, hvis eksaminanden bevæger sig i en forkert retning (Laugesen \& Kristensen, 1999; Kristensen, 2014). Enkelte kilder anbefaler eksaminander en offensiv tilgang til eksaminationen, så denne ikke 'fär karakter af spredehag/sspørgsmål med punktnedslag tilfældige steder i dit pensum' (Hedelund \& Stray Jørgensen, 2004 s. 28). Eksaminanden skal ifølge Fibiger og Søgaard (2009) søge at bevare 'serveretten' ved gennem det indledende mundtlige oplæg at lægge op til, hvilke punkter der skal diskuteres. Leth Andersen og Tofteskov (2008) mener omvendt, at det er en misforståelse, at den bedste eksamensstrategi består i, at eksaminanden selv styrer eksaminationen.

De fleste eksaminatorer i det aktuelle studie mener, at eksaminanden skal have mulighed for en vis grad af styring, og kun en enkelt eksaminator ekspliciterer en direkte modstand mod dette. På trods heraf er det suverænt eksaminatorerne, der styrer eksaminationerne. Den svage grad af studenterstyring kan ikke forklares ud fra eksaminandernes billede af den gode eksamenspræstation, idet de er af den opfattelse, at det er godt, hvis de kan tage en rolle i styringen. Den svage grad af studenterstyring kan heller ikke forklares med fagligt svage eksaminander, der ikke magter at formulere relevante temaer, da de fleste eksaminander fik fine bedømmelser. Baggrunden skal nok snarere findes hos eksaminatorerne, der er underlagt et relativt stort tidspres $i$ at skaffe sig et relevant og nuanceret bedømmelsesgrundlag. Eksaminatorernes grundige forberedelse, med indkredsning af tematikker for eksaminationen og $i$ mange tilfælde også formulering af spørgsmål, kan også have betydning for eksaminandernes muligheder.

Censorerne følger, med få undtagelser, rolleforventningen beskrevet i flere kilder. De har en relativ tilbagetrukken og afventende rolle og går kun ind med enkelte spørgsmål efter tilladelse fra eksaminator (Hørdam, Hundborg \& Christiansen, 2011; Leth Andersen \& Tofteskov, 2008; Laugesen Kristensen, 1999; Kristensen, 2014). Agersnap 
(2004) fremfører, at censor med fordel kan spille en mere aktiv rolle under eksaminationen. I de to tilfælde, hvor censor var aktiv, blev eksaminator presset på styringen af eksaminationen, og eksaminanderne fik slet ikke mulighed for at påvirke forløbet. Der er ikke lovgivningsmæssige restriktioner i forhold til en aktiv censorrolle, men hvis eksaminator og censor skal have en mere ligestillet rolle, synes det at kræve en relativ stor enighed og aftalt arbejdsdeling.

\section{Hvad bestemmer indholdet i eksaminationen?}

Eksaminatorerne følger anbefalingerne i flere kilder, når den indholdsmæssige styring af eksaminationerne bestemmes på baggrund af tematikker udledt af projektopgaverne (Hørdam, Hundborg \& Christiansen, 2011; Laugesen Kristensen, 1999; Agersnap, 2004). Det er især svagheder i det skriftlige produkt, eksaminatorerne tager fat i. Det kan på den ene side medvirke til, at eksaminanden får mulighed for at forbedre sine valg og argumenter, men på den anden side kan det svække eksaminandens mulighed for at demonstrere dybde i sin viden på områder, hvor denne står stærkere. Den almindelige eksaminationsstrategi synes at være valg af et antal tematikker, som giver mulighed for en vis dybde i eksaminationen. Der er enkelte eksempler, hvor eksaminator bevæger sig rundt i så mange temaer, at eksaminationen får et overfladisk præg. Der er enkelte eksempler, hvor eksaminationen afgrænses til få temaer, idet svagheder i den studerendes argumentation forfølges med flere underspørgsmål. Om denne afgrænsning i eksaminationen i bredden opvejes i voteringen, hvor det skriftlige produkt også indgår, kan ikke vurderes.

Flere kilder fremhæver, at eksaminator skal være fleksibel og vise evne til eksempelvis at opgradere eller sænke sværhedsgraden i spørgsmålene, afhængig af den studerendes svar på det forudgående spørgsmål (Hørdam, Hundborg \& Christiansen, 2011; Kristensen, 2014; Leth Andersen \& Tofteskov, 2008). Det virker, som om eksaminatorerne i de fleste tilfælde evner at improvisere og situationstilpasse eksaminationen, men der er også eksempler på, at forudbestemte tematikker og udformede spørgsmål kan svække situationstilpasning af eksaminationen.

Flere kilder peger på kriterier og mål for prøven som centrale styringsredskaber (Hørdam, Hundborg \& Christiansen, 2011; Leth Andersen \& Tofteskov, 2008), hvilket er i overensstemmelse med Bekendtgørelse om prøver i erhvervsrettede videregående uddannelser (Undervisningsministeriet, 2014): 'Eksaminationen skal dokumentere graden af målopfyldelse i forhold til væsentlige mål og krav' (§3, stk. 1). Det er få eksaminatorer, der på eget initiativ fremhæver prøvekriterierne som støtteredskab i tilrettelæggelse af eksaminationerne. Det kan have sammenhæng med, at målene i de aktuelle kriterier er formuleret i meget overordnede termer. 


\section{Hvad har betydning for samspillet under eksaminationen?}

Flere kilder er inde på, at overgangen fra vejlederrollen til eksaminatorrollen rummer udfordringer, og at eksaminator kan bære sin forforståelse af eksaminanden med ind i læsning af projektopgaven, udvælgelse af tematikker, formulering af spørgsmål og i afvikling af eksaminationen som helhed (Agersnap, 2004; Hørdam, Hundborg \& Christiansen, 2011; Leth Andersen \& Tofteskov, 2008; Ingenkamp og Wolf, 1982).

Eksaminanderne fremhæver spontant eksaminatorernes personligheder og deres relation til eksaminator som betydningsfuld for eksaminationen, mens eksaminatorerne ikke har meget opmærksomhed på dette. Den svagere opmærksomhed på dette forhold er, ifølge Leth Andersen og Toftegaard (2008), typisk for eksaminatorer. Alene det forhold at eksaminanderne tillægger det så stor betydning, kan pege på behovet for øget opmærksomhed på relationens betydning.

Kilder om eksamination anbefaler, at eksaminator er opmærksom på at optræde neutral, men også anerkendende og venlig under eksaminationen. Øjenkontakt, kropssprog, indretning af eksamenslokalet og venlig modtagelse af eksaminanden nævnes som betydningsfuld, for at eksaminanderne kan bevare roen og præstere bedst muligt (Hørdam, Hundborg \& Christiansen, 2011; Leth Andersen \& Laugesen Kristensen, 1999; Leth Andersen \& Tofteskov, 2008; Kristensen, 2014). De fleste eksaminatorer følger disse anbefalinger, og eksaminanderne registrerer det. I de få tilfælde, hvor eksaminanderne opfatter en eksaminator som lukket og ikke oplever at modtage verbal eller nonverbal anerkendelse, tillægger de det stor betydning for deres præstation. I nogle eksaminationer forekommer eksaminatorerne meget neutrale i såvel deres nonverbale som verbale kommunikation, uden at det tilsyneladende har negativ indvirkning på de studerende. I disse tilfælde har eksaminanderne en positiv oplevelse af eksaminator fra vejledningsforløbet, som de tilsyneladende bærer med ind i eksamenslokalet.

Hørdam, Hundborg og Christiansen (2011) mener ikke, at eksaminator under eksaminationen skal tilkendegive, hvis besvarelser eller redegørelser ikke er korrekte eller fyldestgørende. Agersnap (2004) finder det omvendt vigtigt, at eksaminator ikke alene bekræfter korrekte svar, men diskret gør opmærksom på fejl ved eksempelvis at bede om en uddybning af en påstand. Det er den sidstnævnte strategi, som de fleste eksaminatorer synes at følge. I to eksaminationer anvendte eksaminator og censor en relativ konfronterende verbal eksaminationsstil, hvor svagheder i besvarelser blev påpeget. De to eksaminander synes dog indforstået med formen, som de tilsyneladende kendte fra andre eksaminationer.

Der er ikke noget entydigt svar på, om eksaminander skal konfronteres med svagheder i deres svar, men der var eksempler på, at en manglende bevidsthed hos eksaminanderne om svagheder undervejs i eksaminationen førte til frustration i forbindelse med karakterafgivelsen. 


\section{Hvor troværdig er eksaminationen?}

Jacobsen og Lauvås (2013) mener, at eksaminationerne sjældent indfanger væsentlige kompetencer, der er brug for i professionsuddannelser, men snarere retter sig mod såkaldt 'kodificeret' viden fra pensum. I de undersøgte eksaminationer kan der findes eksempler på eksaminationer, der efterspørger kodificeret viden, men det gennemgående billede er, at der efterspørges faglige viden i argumentationen for påstande, analyser, metodiske valg, perspektiveringer m.v.

Engvik, Kvale og Havik (1970) konstaterer, at der er store forskelle i eksaminatorernes afvikling af mundtlige eksaminationer, hvilket undersøgelsen kan bekræfte. Reliabiliteten i de mundtlige eksaminationer kunne muligvis hæves, hvis eksaminatorerne oftere tog udgangspunkt i prøvekriterier og mål formuleret heri, hvilket, jævnfør afsnittet om indholdet i eksaminationen, ikke altid er tilfældet. De mener, at denne type eksamination har en lav validitet, hvilket de blandt andet tilskriver et for overordnet og uklart bedømmelsesgrundlag. Vi kan bekræfte, at de meget overordnede målformuleringer i prøvekriterierne efterlader meget til eksaminators fortolkning i både planlægnings-, afviklings- og bedømmelsesfasen.

\section{Metodediskussion}

Det indledende pilotprojekt med undersøgelse af fem eksaminationer bidrog til forfinelse af undersøgelsesdesignet, interviewguides og observationssystematik samt til træning i observations- og interviewteknik, hvilket medvirkede til, at hovedprojektet fik styrket kvaliteten af de genererede data.

Den teoretiske baggrund for udvikling af kodningskategorierne var bred, men byggede overvejende på nordiskfunderet teori af overvejende erfaringsbaseret karakter og i mindre grad på international forskning i mundtlig eksamination, da vi ikke fandt dette.

Metodetrianguleringen med anvendelse af observationsstudier, lydoptagelser og interview med de involverede gav et righoldigt og nuanceret datamateriale om eksaminationerne. Den tætte sammenhæng mellem observationer af eksaminationerne og efterfølgende semistrukturerede interview blev udnyttet til at kontekstualisere disse.

Forskertrianguleringen, herunder forskernes forskellige professionsfaglige udgangspunkt, skærpede analyserne med brud med kulturel forforståelse knyttet til de involverede professions-, uddannelses- og eksaminationskulturer.

Pilotprojektet, metodetriangulering, analysemetoden og forskertriangulering har bidraget til at styrke undersøgelsens interne validitet. Da eksaminationerne tog udgangspunkt i specifikke projekter og blev gennemført med forskellige aktører i forskellige uddannelser, er det et vilkår, at de vil forløbe forskelligt, men med de samme eksaminationer og samme design ville der være mulighed for relativ stor reliabilitet, hvis undersøgelsen blev gentaget. 


\section{Konklusion}

At varetage eksaminatorrollen ved den afsluttende bacheloreksamen er en kompleks og udfordrende opgave, hvor der skal foretages komplicerede valg, når den relativt sparsomme eksaminationstid skal bruges optimalt til at skaffe et relevant bedømmelsesgrundlag. Der er en række spændingsfelter, som eksaminator skal navigere i, eksempelvis mellem dybde og bredde i eksaminationen, styring af eksaminationen samt en støttende versus udfordrende tilgang i eksaminationen.

Det kan konstateres, at eksaminatorerne administrerer disse spændingsfelter på forskellig vis. Nogle af disse forskelle kan forklares med, at eksaminationerne er tilpasset konkrete eksaminander og tager udgangspunkt i specifikke skriftlige projekter. Der er også forskelle, som kan tilskrives personlig eksaminationsstil og kulturelle aspekter knyttet til uddannelserne.

Forforståelsen af eksaminanden og stemning under eksaminationen kan have indbyrdes sammenhæng og kan få betydning for eksaminationen, og især forforståelsens betydning synes at være et lidt underkendt aspekt i eksaminatorernes tilgang til eksamination.

Prøvekriterierne er ikke specielt retningsanvisende for eksaminatorer i tilrettelæggelse af eksaminationen.

\section{Perspektivering}

Mundtlig eksamination på baggrund af et større skriftligt projekt burde være mere i fokus i kompetenceudviklingen af underviserne på uddannelsesinstitutionerne. Undervisning i eksaminatorrollen med indlagt supervisionstilbud kunne sandsynligvis højne kvaliteten af eksaminationerne.

Censorordningen har fokus på kvalitetssikring af eksaminationer, men det er spørgsmålet, om uddannelsesinstitutionernes interne kvalitetssystemer også på anden vis burde fokusere på mundtlige eksaminationer på baggrund af større projektrapporter, da der kan være behov for at øge disses reliabilitet og validitet.

Der kunne være behov for yderligere deskriptiv forskning om afvikling af mundtlige eksaminationer på baggrund af større projektrapporter på andre uddannelser og uddannelsesinstitutioner. Der kan være behov for forskning i hele forløbet fra vejledning over projekt og eksamination til votering, som kunne bidrage til en mere nuanceret forståelse af sammenhængen i eksamen som helhed.

Thomas Würtz Jensen er lektor i VIA og uddannet fysioterapeut og Master i IKT og Iæring. Han har i en lang årrække beskæftiget sig med undervisning på fysioterapeutuddannelsen. Desuden har han gennemfort forsknings- og udviklingsarbejder primært med fokus på didaktik hvor it-redskaber indgår. Ud over at undervise er han tilknytte Videncenter for IT og Læring i VIA og har skrevet flere artikler om anvendelse af it som redskab til læring. 
Carsten Nielsen er uddannet sygeplejerske og cand.pæd. Han har i en lang årrække beskæftiget sig med undervisning på sygeplejerskeuddannelsen. Han har medvirket i mange udviklings- og forskningsarbejder med fokus på didaktiske aspekter på sygeplejerskeuddannelsen, herunder læring af sygepleje i det kliniske felt. Han er medforfatter til flere bøger og artikler om didaktiske spørgsmål i professionsuddannelser. Han arbejder aktuelt som uddannelseskoordinator ved Sygeplejerskeuddannelsen i Aarhus med overordnet ansvar for tilrettelæggelsen af såvel den teoretiske som kliniske undervisning.

Winnie Westergaard Høgsaa er uddannet sygeplejerske og cand.cur. Hun har i en lang årrække beskæftiget sig med undervisning på sygeplejerskeuddannelsen, især på uddannelsens sidste år, hvor de studerende forberedes til bacheloreksamen. Hun har stor erfaring med afvikling af bacheloreksamen både som vejleder, eksaminator og som censor.

\section{Litteratur}

Agersnap, F. (2004). Mundtlig eksamen: vejledning for lærere. Frederiksberg: Samfundslitteratur.

Borgnakke, K. (2013). Etnografiske metoder i uddannelsesforskningen: mellem klassiske traditioner og senmoderne udfordringer. [Kbh.]: Institut for Medier, Erkendelse og Formidling, Københavns Universitet.

Elo, S., \& Kyngäs, H. (2008). The qualitative content analysis process. Journal of Advanced Nursing, 62(1), 107-115.

https://doi.org/10.1111/j.1365-2648.2007.04569.x

Engvik, H., Kvale, S., \& Havik, O. E. (1970). Rater Reliability in Evaluation of Essay and Oral Examinations. Pedagogisk Forskning, 14(1), 195-220.

https://doi.org/10.1080/0031383700140111

Fibiger, J., \& Søgaard, S. (2009). Genvejstaster: til opgaveskrivning og faglig formidling på bacheloruddannelserne (Bd. 1. udgave). Århus: Academica.

Hedelund, L., \& Stray Jørgensen, P. (2004). Mundtlig eksamen med skriftligt materiale/synopsis. Frederiksberg: Samfundslitteratur.

Hørdam, B., Hundborg, S., \& Christiansen, R. B. (2011). Eksamen \& censur i professionsbacheloruddannelserne: en håndsrækning til vejledere, eksaminatorer, censorer og studerende (Bd. 1. udgave). Kbh.: Unge Pædagoger.

Ingenkamp, K., \& Wolf, B. (1982). Research in Oral Secondary School Leaving Examinations in Germany. British Journal of Educational Psychology, 52, t3341-49.

Jakobsen, A., \& Lauvås, P. (2013). Eksamen - eller hvad?: former for summativ evaluering i professionsuddannelser. Kbh.: Nota. Hentet fra http://www.e17.dk/bog/610289

Kristensen, E. L. (2014). Mundtlig eksamination med succes: bedre resultater med en mere struktureret forberedelse og eksamination: inspiration for især eksaminator og censor. Silkeborg: ELKI-SP. 
Krueger, R. A. (2015). Focus groups: a practical guide for applied research (5th edition). Thousand Oaks, California: SAGE.

Kvale, S. (2015). InterViews: learning the craft of qualitative research interviewing (Third edition). Los Angeles: Sage Publications.

Laugesen Kristensen, E. (1999). Mundtlig eksamination: 7-fasemodellen - en model til brug ved strukturering af det mundtlige eksaminationsforløb. Silkeborg: ELKISP.

Leth Andersen, H., \& Tofteskov, J. (2008). Eksamen og eksamensformer: betydning og bedømmelse (Bd. 1. udgave). Frederiksberg: Samfundslitteratur.

Polit, D. F., \& Beck, C. T. (2004). Nursing research: principles and methods (7th ed). Philadelphia: Lippincott Williams \& Wilkins.

Polit, D. F., \& Beck, C. T. (2012). Nursing research: generating and assessing evidence for nursing practice. Philadelphia: Wolters Kluwer Health/Lippincott Williams \& Wilkins.

Undervisningsministeriet. (2014, 01). Erhvervsrettet eksamensbekendtgørelse - Bekendtgørelse om prøver og eksamen i grundlæggende erhvervsrettede uddannelser - retsinformation.dk. Hentet 4. februar 2015, fra https://www.retsinformation.dk/forms/R0710.aspx?id=161427\#Kap7 